\title{
Development and Evaluation of Physicochemical and Nutritional Properties of pasta with fortification of aonla powder
}

\author{
Piyush Mishra*, Devendra Kumar Bhatt \\ Institute of Food Technology and science (Center of Excellence), Bundelkhand University, Jhansi-284128, \\ Uttar Pradesh, India
}

\begin{abstract}
Pasta is a popular, nutritious and low glycaemic food having global appeal as nutrition supplement. Fortifications of pasta with a variety of proteins increase the nutritional significance of pasta and improve the health condition of the immense majority of health conscious peoples. In present study we developed three samples (C, C1, C2, and C3) of pasta using refined wheat flour and proportions of aonla powder. Sample C was prepared as control containing only refined wheat flour (100\%), while sample Cl (refined wheat flour $99 \%$ and aonla powder 1\%), C2 (refined wheat flour 97\% and aonla powder 3\%), C3 (refined wheat flour 95\% and aonla powder 5\%) were prepared by changing the concentration of refined wheat flour and different aonla powder. All the three samples were evaluated for the physicochemical properties (moisture content, ash value and texture analysis) nutritional properties (carbohydrate, protein, fibre and fat), cooking time and sensory qualities. A aonla powder fortified pasta product was successfully produced and it was observed as the concentration of aonla powder was increased the cooking time also increased. On the basis of physicochemical \& nutritional properties cooking time and sensory qualities, pasta containing refined wheat flour (97\%) and aonla powder (3\%) resulted in better quality having more nutritional elements and highest overall acceptability. Keywords: Pasta, fortification, protein supplementation, nutrition, health conscious peoples.
\end{abstract}

\section{Introduction}

Pasta is a most popular food in India serve as a fast food with vegetables and souses. It is mostly attracting the children's and the younger generation of India. it is commonly made by refined wheat flour if its neutraceutical value is enhanced than it can also be consider as a healthy pasta to take its health benefits. Refined wheat flour is mixed with aonla powder with the addition of water after that it put into the pasta extruder machine and kneaded after that it is extruded in different shapes. Aonla is arid fruits popularly known as "Indian gooseberry" a small sized minor subtropical fruit grows widely in North India. India ranks first in the world in area and production. It is considered as "Wonder fruit for health" because of its unique qualities. It is a rich source of vitamin C. It is a perishable fruit and therefore it is necessary to extend its shelf life by adopting good post harvest management practices. Post harvest loses are the major constraints which discourage farmers to go for Aonla cultivation. The extension of shelf life may be possible by checking the rate of transpiration, respiration and by checking microbial infection. There are so many products like Aonla squash, candy, jam and chutney prepared from fruit. Inclusion of these products in diet defiantly helps in improving the nutritional value of Indian meal. Low cost of the products as well as good sensory, nutritional and shelf life qualities establish that the processed Aonla products are appropriate for commercialization. In order to have good income from Aonla, it must be sold immediately in the market. To get profit, proper storage facilities should be available. Processed Aonla products also have greater scope in future.

The health benefits of Indian Gooseberry, also known as Amla, can be partially attributed to its high vitamin- $\mathrm{C}$ content. Amla enhances food absorption, balances stomach acid, fortifies the liver, nourishes the brain and mental functioning, supports the heart, strengthens the lungs, regulates elimination of free radicals, enhances fertility, helps the urinary system, increases skin health, promotes healthier hair, acts as a body coolant, flushes out toxins, increases vitality, strengthens eyes, improves muscle tone and, acts as an antioxidant. This fruit ripens in the autumn in wet, forested, hilly areas on the Indian subcontinent. In India it is considered a sacred tree. The fruit is very nourishing, but it tastes sour. Both dried and fresh fruits can be consumed for their health benefits.

It provides remedies for many diseases, so it is widely used in Ayurvedic treatment. Gooseberry is very rich in Vitamin C, and contains many minerals and vitamins like Calcium, Phosphorus, Iron, Carotene and Vitamin B Complex. Amla is also a powerful antioxidant agent.

Many health problems are caused by oxidative damage (when body cells use oxygen, they produce byproducts called free radicals that can cause damage). Antioxidant agents prevent and repair these damages. Vitamin-C is a good antioxidant agent, which makes gooseberries a powerful tool against a variety of conditions, including various types of cancer. 


\subsection{Procurements of raw material}

\section{Material And Method}

Aonla powder and wheat flour (Triticum aestivam) is used and procured from local market.

\subsection{Evaluation of physicochemical properties of raw material}

The content of protein was determined as per (IS: 7219:1973): Kjeldhal method, protein content was obtained by using the conversion factor of 6.25, crude fibre was determined by (IS: 11062) and carbohydrate content by difference method, ash and fat content were determined according to AOAC 2000 methods.

\subsection{Sample preparation}

Four Samples (C, C1, C2, and C3) were prepared using sample C as control containing only refined wheat flour (100\%), while sample C1, C2 and C3 were prepared using different concentration of refined wheat flour and Aonla powder. Proximate composition and concentration of different raw materials taken in the preparation of control (C) and other samples (C1-C3) is shown in Table 1. All the samples were passed separately through sieve no. 10 thrice to improve the mixing. Prepared samples were stored in an air tight polyethylene bag in cool and dry place for further study.

Table.1 Chemical composition of raw materials

\begin{tabular}{|l|l|c|c|c|}
\hline Ingredient & \multicolumn{2}{|c|}{ Sample } \\
\hline Sample & C & C1 & C2 & C3 \\
\hline Refind wheat flour & 1000 & 990 & 970 & 950 \\
\hline Aonla Powder & - & 10 & 30 & 50 \\
\hline
\end{tabular}

\subsection{Pasta Preparation}

Different samples of pasta $(\mathrm{C}, \mathrm{C} 1, \mathrm{C} 2$ and $\mathrm{C} 3)$ is prepared using different concentrations of refined wheat flour and Aonla powder in the ratio of 100:00; 99:01; 97:03, 95:05 respectively. In each case, an amount of $1000 \mathrm{~g}$ of the respective composition was taken for the preparation of pasta. Refined wheat flour and aonla powder is mixed with optimum amount of water in the mixing chamber of pasta extruder (Le Monferrina Masoreo Arturo and C.S.N.C., Italy) for 10 minute to distribute the water uniformly. The moist flour aggregate was extruded through pasta extruder fitted with an adjustable die. The speed of revolving sharp blade cutter in the front of the die was adjusted so that the length of the pasta finished at $2 \mathrm{~cm}$ for each sample. Drying of final pasta sample was carried out in hot air oven at $75^{\circ} \mathrm{C}$ for $3 \mathrm{~h}$. The dried product was packed in polyethylene bags. The main objective of the drying was to reduce the moisture content of the sample to about 8-10\%. Final dried products of various samples were packed in high density polyethylene bags. The resultant dried products were then used for further study such as cooking time, chemical composition, viscosity, texture and sensory analysis.

\subsection{Evaluation and optimization of pasta samples}

The developed pasta products were analyzed for their different quality parameters. The cooking quality of samples was determined by the minimum cooking time as per AACC 2000. Rapid visco analyzer (RVA) was used to determine the pasting properties of raw material of pasta products. The texture of the product was determined with the help of stable micro system texture analyzer TA-XT2i. It was used in cutting mode to record the required force to cut the pasta sample. Sensory evaluation was carried out as per 9 point hedonic scale with the degree of liking: 1 = extremely dislike, to $9=$ extremely like. Each pasta sample was cooked separately in a stainless steel pan, in the each case $100 \mathrm{~g}$ pasta sample was taken and cooked in $500 \mathrm{ml}$ of water. The pasta was added in to the boiling water and was boiled for the time already determined. Boiled pasta was then drained, fried in a pre standardized method by using oil, mustard, onion and tomato with salt and used for sensory evaluation. A ten member panel of panellists evaluated the cooked samples of pasta and marked their observations in the sensory card. Each of the samples was randomly numbered using a three-digit code. Pasta was evaluated for colour, texture, aroma, taste and overall acceptability.

\subsection{Statistical analysis.}

The results are expressed as Mean \pm SD (standard deviation). The statistical significance was analyzed using One-way Analysis of Variance (ANOVA) followed by Dunnett Multiple Comparisons Test by employing statistical software, Graph Pad, Instate 3. Differences between groups were considered significant at $\mathrm{P}<0.05$ level.

III. Results and Discussions

3.1. Evaluation of chemical composition of raw material The composition of the raw material is depicted in Table 2 
Table.2.Chemical composition of raw materials

\begin{tabular}{|l|l|l|l|l|l|}
\hline Raw material & Carbohydrate & Protein & Fat & Fibre & Ash \\
\hline $\begin{array}{l}\text { Refined wheat } \\
\text { flour }\end{array}$ & $73.60 \pm 0.03$ & $10.68 \pm 0.10$ & $1.20 \pm 0.08$ & $0.50 \pm 0.15$ & $3.60 \pm 0.04$ \\
\hline Aonla powder & $16.79 \pm 0.01$ & $5.02 \pm 0.12$ & $0.30 \pm 0.01$ & $2.40 \pm 0.03$ & $1.28 \pm 0.01$ \\
\hline
\end{tabular}

\subsection{Nutritional composition of prepared pasta samples}

The protein content of C, C1, C2 and C3 pasta samples were found to be 9.72, 9.52, 9.40, and 9.22 respectively. Fortification of pasta with different level of aonla powder lightly decreases the carbohydrate, protein, fat and ash content of the final products. While fibre content of prepared aonla pasta increases in comparison to control pasta, the result agreed with other researchers. The nutritional composition of prepared pasta samples is shown in Table 3.

Table.3. Nutritional composition of prepared pasta samples

\begin{tabular}{|l|l|l|l|l|l|}
\hline sample & Carbohydrate & Protein & Fat & Fibre & Ash \\
\hline C & $72.00 \pm 0.60$ & $9.72 \pm 0.21$ & $1.10 \pm 0.02$ & $0.46 \pm 0.01$ & $3.52 \pm 0.04$ \\
\hline C1 & $72.00 \pm 0.56$ & $9.52 \pm 0.90$ & $1.16 \pm 0.02$ & $0.52 \pm 0.05$ & $3.38 \pm 0.09$ \\
\hline C2 & $73.15 \pm 0.46$ & $9.40 \pm 0.89$ & $1.10 \pm 0.05$ & $0.52 \pm 0.03$ & $3.08 \pm 0.04$ \\
\hline C3 & $73.00 \pm 0.42$ & $9.22 \pm 0.60$ & $1.06 \pm 0.02$ & $0.52 \pm 0.02$ & $2.92 \pm 0.08$ \\
\hline
\end{tabular}

Note: All value are represented as Mean \pm S.E.M. (standard error mean), $n=6$; data were analyzed by one-way ANOVA (Analysis of variance) employing Dunnett Multiple Comparisons Test using Graph Pad, Instate 3 software. Where $\mathrm{C}=\mathrm{Control}$ sample, $\mathrm{C} 1=1 \%$ aonla powder sample, $\mathrm{C} 2=3 \%$ aonla powder sample, $\mathrm{C} 3=5 \%$ aonla powder sample.

3.3. Cooking time. Cooking time of pasta sample was significantly decreased as compare to the control sample, in each case $50 \mathrm{~g}$ of each sample was taken and cooked separately for the evaluation of cooking time. The result is shown in Table 4.

Table.4.Cooking time of prepared pasta sample

\begin{tabular}{|l|l|}
\hline sample & Cooking time (minute) \\
\hline $\mathrm{C}$ & $5.48 \pm 0.02$ \\
\hline $\mathrm{C} 1$ & $5.10 \pm 0.15$ \\
\hline $\mathrm{C} 2$ & $4.72 \pm 0.07$ \\
\hline $\mathrm{C} 3$ & $4.32 \pm 0.10$ \\
\hline
\end{tabular}

Note: All value are represented as Mean \pm S.E.M. (standard error mean), $n=6$; data were analyzed by one-way ANOVA (Analysis of variance) employing Dunnett Multiple Comparisons Test using Graph Pad, Instate 3 software, $* \mathrm{P}<0.05$.

3.4. Visco-elastic properties - Rapid visco analyzer (RVA, Starch Master of Perten, Sweden) was used to determine the pasting properties of raw material of pasta products. The peak viscosity (maximum viscosity of the sample during the heating and holding phase of the procedure) as well as the final viscosity (viscosity reading at the end of the test profile) was recorded for all samples. Sample is cooked at $95^{\circ} \mathrm{C}$ then cooled to $65^{\circ} \mathrm{C}$, and its viscosity measured, using a RVA. The paste temperature of $65^{\circ} \mathrm{C}$ is used to rapidly stabilize viscosity and minimize retro gradation.

Table.5.Viscosity Value Of Different Samples

\begin{tabular}{|l|l|l|l|}
\hline Sample & Peak viscosity & Hold viscosity & Final viscosity \\
\hline C & $2533.00 \pm 588.26$ & $1985.00 \pm 447.96$ & $2189.00 \pm 167.49$ \\
\hline C1 & $2870.00 \pm 516.65$ & $1870.66 \pm 50.29$ & $3208.33 \pm 70.08$ \\
\hline C2 & $2380.00 \pm 51.46$ & $1585.66 \pm 50.29$ & $2758.33 \pm 70.08$ \\
\hline C3 & $3109.66 \pm 281.43$ & $1973.00 \pm 253.30$ & $3374.66 \pm 269.60$ \\
\hline
\end{tabular}

It was found that there was significant difference in the peak viscosity and hold viscosity among different samples $(\mathrm{P}<0.05)$.

Table .6. Different variables of rapid viscosity

\begin{tabular}{|l|l|l|l|l|l|l|}
\hline Sample & variables & Sum of square & DF & Mean square & F Value & SIG \\
\hline \multirow{5}{*}{ Peak Viscosity } & Between group & 974607.00 & 3 & 324869.00 & 1.870 & .213 \\
\cline { 2 - 7 } & Within group & 1389672.66 & 8 & 173709.00 & & \\
\cline { 2 - 7 } & Total & 2364279.66 & 11 & & 1.079 & .411 \\
\hline \multirow{3}{*}{ Hold Viscosity } & Between group & 310805.58 & 3 & 103601.86 & & \\
\cline { 2 - 8 } & Within group & 768013.33 & 8 & 96001.60 & & \\
\cline { 2 - 8 } & Total & 1078818.91 & 11 & & & \\
\hline
\end{tabular}


Development and Evaluation of Physicochemical and Nutritional Properties of pasta with

\begin{tabular}{|l|l|l|l|l|l|l|}
\hline Final Viscosity & Between group & 2534264.91 & 3 & 844754.97 & 10.416 & .004 \\
\cline { 2 - 7 } & Within group & 648818.00 & 8 & 81102.25 & & \\
\cline { 2 - 7 } & Total & 3183082.91 & 11 & & & \\
\hline
\end{tabular}

Note: All value are represented as Mean \pm S.E.M. (standard error mean), $n=6$; data were analyzed by one-way ANOVA (Analysis of variance) employing Dunnett Multiple Comparisons Test using Graph Pad, Instate 3 software, $* \mathrm{P}<0.01$

3.5. Texture analysis. The texture of the samples was analyzed and it was found that the force (in g) required to cut the pasta sample was decreasing with increasing amount of aonla powder. The results of the analysis are presented in the table No 6. The cutting force of C, C1, C2 and C3 were 2410.12 $\pm 0.40,2392.00 \pm 1.07$, $2129.90 \pm 1.60,1843.00 \pm 0.87$, respectively. The increase in the percentage of aonla powder is resulting in the softer texture of the product.

Table.7.Cutting force (g) of the pasta samples

\begin{tabular}{|l|l|}
\hline Sample & Aonla powder \\
\hline C & $1913.23 \pm 28.35$ \\
\hline C1 & $1870.18 \pm 98.42$ \\
\hline C2 & $1778.45 \pm 101.48$ \\
\hline C 3 & $1496.67 \pm 58.59$ \\
\hline
\end{tabular}

Note: All value are represented as Mean \pm S.E.M. (standard error mean), $n=6$; data were analyzed by one-way ANOVA (Analysis of variance) employing Dunnett Multiple Comparisons Test using Graph Pad, Instate 3 software, $* \mathrm{P}<0.01$.

\subsection{Sensory characteristics}

Sensory evaluation of the products was carried out by using 9 point hedonic scale sensory test. The colour score of $\mathrm{C}, \mathrm{C} 1, \mathrm{C} 2$ and $\mathrm{C} 3$ samples was 7.6 $\pm 0.96,7.00 \pm 0.66,6.9 \pm 0.72,7.0 \pm 0.81$ respectively. It was observed that the colour of $\mathrm{C} 2$ was found best among all samples. The flavour score of $\mathrm{C}, \mathrm{C} 1, \mathrm{C} 2$ and $\mathrm{C} 3$ samples was7.7 $\pm 0.67,6.50 \pm 0.97,7.8 \pm 0.32,8.3 \pm 0.82$ respectively. The score of $\mathrm{C} 2$ was found best in sensory evaluation. The texture, taste and overall acceptability score of $\mathrm{C} 2$ was7.5 $\pm 0.97,7.20 \pm 0.78,7.1 \pm 0.87$, and $7.8 \pm 0.91$ respectively. There was improvement in colour and texture of the product. The taste might have some change with increasing concentration of aonla pasta. The product with 3 percent aonla pasta was found better in comparison to other combinations.

\section{Hardness}

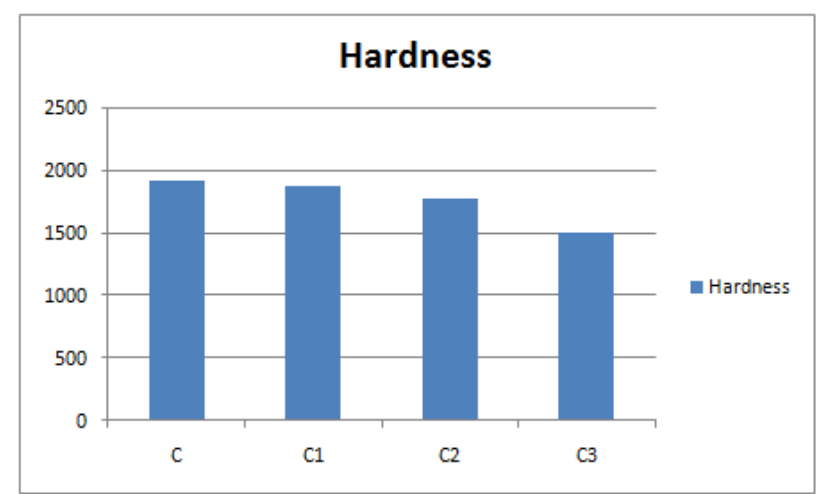

Fig 1 : Graphical representation of hardness of different pasta samples.

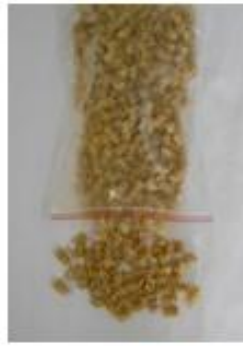

Control Sample

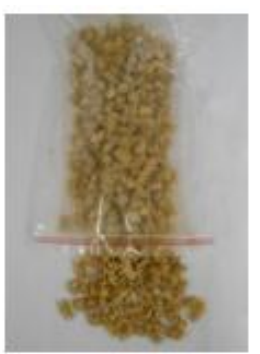

Sample C1 


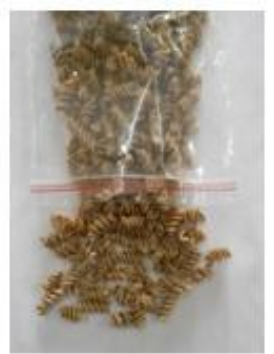

Sample C2

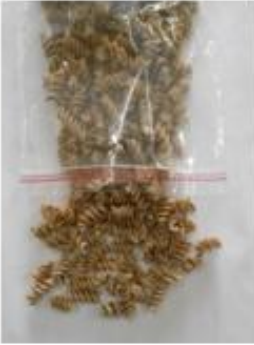

Sample C3

Table 8. Sensory scores of prepared pasta samples

\begin{tabular}{|l|l|l|l|l|l|}
\hline Sample & \multicolumn{4}{|l|}{ Sensory parameters } \\
\cline { 2 - 6 } & Colour & Flavour & texture & taste & Overall acceptability \\
\hline C & $7.6 \pm 0.96$ & $7.7 \pm 0.67$ & $7.5 \pm 0.97$ & $7.4 \pm 0.69$ & $7.9 \pm 0.87$ \\
\hline C1 & $7.00 \pm 0.66$ & $6.50 \pm 0.97$ & $7.20 \pm 0.78$ & $7.50 \pm 1.26$ & $7.70 \pm 1.25$ \\
\hline C2 & $6.9 \pm 0.72$ & $7.8 \pm 0.32$ & $7.1 \pm .87$ & $8.0 \pm 0.66$ & $7.7 \pm 0.59$ \\
\hline C3 & $7.0 \pm 0.81$ & $8.3 \pm 0.82$ & $7.8 \pm 0.91$ & $7.9 \pm 0.99$ & $8.2 \pm 0.91$ \\
\hline
\end{tabular}

\section{Conclusion}

The pasta was prepared with different proportions of aonla powder. The results showed that with increase in aonla concentration the fibre content increased and the cooking time decreased and the softness of pasta increased more than the control sample. It was found that the final viscosity of the sample was increasing with increase of aonla powder. Fortified pasta was highly acceptable with respect to sensory attribute and cooking time. On the basis of physico-chemical and nutritional properties, cooking time analysis of viscosity and sensory qualities pasta certain $97 \%$ refine wheat flour and 3\% aonla powder (sample C2) resulted in better quality having more and high overall acceptability. aonla powder prevents different diseases (diabetes, asthma, arthritis and heart diseases etc.). If we include aonla powder pasta in daily life style, it's prevent many diseases.

\section{Acknowledgements}

The present study was supported by the Centre of Excellence Uttar Pradesh India, and Bundelkhand University Jhansi, Uttar Pradesh India, to provide the necessary research facilities for the successful completion of research work.

\section{Conflict of Interest}

The authors declare no conflict of interest.

\section{References}

[1]. Suresh Kumar P, Sagar VR. Influence of packaging materials and storage temperature on quality of osmo-vac dehydrated aonla segments. J Food Sci. Technol. 2009; 46:259-262.

[2]. B., Jain, S.P., Tripathi, V.K. and Singh, S. 1983.

[3]. H Composition of Aonla (Emblica officinalisGaertn)fruits during growth and development: Part-1. Indian Food Packer 37: 57-60.

[4]. B.P., Singh, I.P., Singh, S.P. and Kumar, K.A. 1987. Physicochemical composition of different cultivars of Aonla. Indian Food Packer 41: 7-10.Naik, A.G. and Chundawat, B.S. (1996).

[5]. Evaluation of Gujarat aonla-1 (Emblica officinalisGarten.) for various processed products.J. Appl.Hort.

[6]. Naik, A.G. and Chundawat, B.S. (1996).Evaluation of Gujarat aonla-1 (Emblica officinalisGarten.) for various processed products.J. Appl.Hort.

[7]. Kumar S, Singh IS (2003) Physico-chemical studies of various cultivars of aonla fruits. Prog Hort 34(1):102-104

[8]. Jain, S.K. and Khurdiya, D.S. (2004).Vitamin C enrichment of fruit juice based RTS beverage through blending of aonla juice. Plant Foods Hum. Nutr.

[9]. Sogi, D.S. and Singh, S. (2001).Studies on bitterness developmentin Kinnow juice ready-to-serve beverage, squash, jam and candy.J Food Sci. Technol.38(5): 433-438.

[10]. Ghorai, K. and Sethi, V.,1996. Varietal suitability of amla (Desi and Banarsi) fruits for storage and preservation. Indian Food packer, 50(1): 11-14.

[11]. Mishra ,Poonam., Srivastava, Vijeyta., Verma, Deepmala., Chauhan, O. P. and Rai1,G. K,2009. Physico-chemical properties of Chakiya variety of Amla (Emblica officinalis) and effect of different dehydration methods on quality of powder. African Journal of Food Science, Vol. 3(10) pp. 303-306

[12]. Sehgal, G.,1997. Development of Aonla (Emblica Officinalis Gaertn.) Honey Spread. Thesis, M.Sc. G.B. Pant University of Agriculture and Technology, Pantnagar. 96 p.

[13]. Sethi, V., 1986. Effect of blanching on drying of amla. Indian Food Packer, 40(4):7-10

[14]. Srivastava, R.P.,1964. Chemical Composition fresh and dried Aonla fruits. Sci. Cult. 30(9):446-447.

[15]. Tripathi, V.K., Singh, M.B., and Singh, Surjeet. 1988. Studies on comparative compositional changes n different preserved products of aonla. Indian Food Pakcer, 42(6):60-66.

[16]. Sung, Wen-Chieh and Stone, Martha, 2003 characterization of various wheat starch in pasta development, Journal of Marine Science and Technology, Vol. 11, No. 2, pp. 61-69. 